Гудков Д.Д.

\title{
Образ воюющего русского и американца в кинематографе: ценностные отличия
}

Аннотация: В исследовании представлены отличия, в первую очередь ценностного характера, образа русского и американского солдата в художественных произведениях. Проведено сравнение ценностного набора американского и русского солдата в условиях достижения единой цели - Победы в конфликте, проанализированы эмоционально-психологические установки и решения, принимаемые в соответствии с ними, а так же продемонстрированы различия в отношении русских и американцев к схожим ситуациям в контексте их ценностного профиля. Анализ охватывает широкий спектр эмпирического материала. Базовыми методами в исследовании выступают контент-анализ художественных произведений, отечественных и зарубежных художественных фильмов и сериалов, а также некоторых литературных произведений, и компаративистский подход. В контексте последних военных конфликтов по всему миру, включая последние события на Украине, войны в Ираке, Сирии, Афганистане, возникает необходимость переосмысления воюющего человека, его ценностного профиля,сравнения ценностных наборов воюющих людей в разные исторические периоды - Вторая мировая война, Въетнам, Чеченская и Грузинская компании. Данная статья содержит результат исследования по данной проблеме, в котором научно обосновывается коренное отличие цеенностных установок американского и русского солдата в условиях достижения победы в конфликте.

Review: The author of the present article describes the differences, first of all, axiological differences, in the images $f$ a Russian soldier and American soldier in fiction and cinematograph. The researcher compares the systems of values of Russian and American soldiers when they strive for the same goal - Victory. The author analyzes their emotions, attitudes and decisions and demonstrates differences in Russian and American attitudes to similar situations from the point of view of their values. The analysis carried out by the author covers a wide range of empiric material. The main research methods are the content analysis of fiction as well as Russian and foreign films and TV serials as well as some literary works. The author applies the comparative approach. The latest war conflicts happening all over the world including the last events in the Ukraine, wars in Iraq, Syria and Afghanistan create the need for re-considering the image of a warning man and his system of values at different historical periods - the Second World War, Vietnam, Chechen and Georgian campaigns. The article presents the results of the research and scientifically proves the main difference in values of an American soldier and Russian soldier under the conditions striving for victory in a war conflict.

Ключевъе слова: Разум, труд, нестяжательство, добро, совесть, душа, религия, вера, патриотизм, семья.

Keywords: Reason, labor, the Nonpossessors movement, good, conscience, soul, religion, faith, patriotism, family.

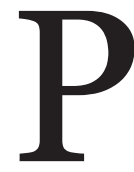

оссии на протяжении столетий пришлось слишком часто воевать, и война в связи с этим стала естественной частью нашего исторического бытия. Поэтому батальная живопись (и вообще искусство русских художников) отобразила не только подвиги народа на разных этапах нашей истории, но и множество бытовых сюжетов и примет воинской жизни, с которой была связана не только армия. То, что художнику Запада казалось Апокалипсисом, для баталистов России было привычными кровью и потом. Наиболее значимыми для создания художественного образа сражающейся
России стали картины о подвиге и трагедии народа в Великой Отечественной войне. Современникам она, в первую очередь, запомнилась по плакатам со всё объясняющими названиями: «Родина-мать зовет» И.М. Тоидзе, «Воин Красной Армии, спаси!» В.Б. Корецкого, «Партизаны, мстите без пощады» T.А. Ереминой, «Папа, убей немца!» М.А. Нестеровой-Берзиной, «Это сделали немцы» А.А. Кокорекина. Военная живопись тех лет - это во многом картины боли и утрат. Военный кинематограф же тех лет - это история Освобождения и помощи, страдания, но и стойкости русского солдата. 
Однако если обратиться к западному виденью русского военного, воюющего русского, то мы увидим дикого, совершенно неадекватного тирана-убийцу с «автоматом Калашникова». Америка со времен ее оформления как самостоятельной державы, со времен первых переселенцев также все время воевала: сначала с коренными жителями, затем за независимость, в гражданской и Первой мировой войнах, Второй мировой, Корее, Вьетнаме, а теперь - в Югославии, Афганистане и Ираке. Это также вырабатывало определенные принципы и образы войны. Можно вспомнить «Рэмбо», «Капитана Харта», Джуда Лоу в «Холодной горе» или Марлона Брандо и Тома Хэнкса в фильмах о Вьетнаме.

Доказано и убедительно показано (работы коллектива авторов Центра научной политической мысли и идеологии), что набор ценностей для большинства человечества приблизительно одинаков. Он раскладывается на определенные реостаты, где те или иные ценности имеют большее или меньшее значение ${ }^{1}$. В данной работе мы посмотрим на ценностный образ воюющих русских и американцев в кинематографе этих стран. Одной из ключевых ценностей практически любого военного фильма является сам ужас и бессмысленность убийства человека человеком. Однако здесь мы и подходим к стереотпизации ${ }^{2}$ и идеологизации многих фильмов, посвященных гражданским войнам - победившая сторона всегда подчеркивает заблуждение и непонимание правильности своих действий со стороны проигравшей стороны. Так, молодые «неуловимые мстители» идеологизируются при сравнении их с омерзительными белыми офицерами, полностью погрузившимися в пьянство и порок. Пример, это образ Овечкина в исполнении Армена Джигарханяна. Сегодня, напротив, фильмы «Гибель империи» или «Адмирал» рисуют красных, эсеров и прочих воюющих на противоположенной стороне - одичалой толпой наркоманов и садистов, раскулачивающих крестьян и насилующих женщин-дворянок, несоблюдающих устав и, в конце концов, просто расстреливающих всех, кто им не нравится, в то вре-

\footnotetext{
${ }^{1}$ Багдасарян В.Э., Сулакшин С.С. Высшие ценности Российского государства. М.: Научный эксперт, 2012. ${ }^{2}$ Термин «стереотип» ввел У. Липпман (Липпман У. Общественное мнение, М., 2004 г.) Означает: устоявшееся отношение к происходящим событиям, действиям, поступкам и т.п. В социологии схоже с понятием «фрейм».
}

мя генерал Капель без ног и без стрелкового оружия берет геройски Иркутск, а герой Балуева в «Гибели империи» защищает старика, продающего сигареты от пьяного красного патруля. В «Унесенных ветром» однозначного отношения, кто прав, а кто виноват, мы не встречаем, хотя, определенно, общую симпатию мы испытываем к конфедератам. Еще более отрицательное отношение к северянам мы испытываем в «Бандах Нью-Йорка». Сначала они записывают в армию всех негров, ирландцев и прочих мигрантов, сходящих с кораблей, а затем расстреливают целый город из пушек, чтобы подавить голодные бунты. Образ Высоцкого в «Служили два товарища», безусловно, вызывает симпатию, как и образ семьи Турбиных у Булгакова. В фильме «Повелитель бури» всегда «идеальный и честный» американский сапер превращается в безумного убийцу, точно так же, как герой Брандо в фильме «Апокалипсис сегодня». В нашем кино мы вспоминаем, ставшие народными «Наплявать, наплявать - надоело воевать». В «Тихом Доне» Мелехов только через ужас гражданской войны, разочаровавшись в войне как таковой - возвращается и подбрасывает на руках сына. То же самое происходит и в «Холодной горе»: герой Лоу сначала честно сражается, потом попадает в плен и бежит домой, где его бывшие соседи, «откосившие от службы», творят бесчинства, и снова погружается в пучину убийств. Прототип героя обороны Крыма Слащева в «Беге» все время видит сон, в котором тысячи слепых солдат мечутся в котловане без цели и направления. Квинтэссенцией этой общей для наших культур тенденции может служить фильм «Дом войны», где солдат просыпается каждый день и сражается с монстром, бесконечно убивая его, но сам становится таким монстром рано или поздно.

Вторым фактором, влияющим на образ воюющего человека, становятся три условия: необходимость (угроза, попытка от чего-то скрыться и т.п.), долг, случайный фактор/внезапность (он в чем-то отличается от первого, но они близки).

В ключевых и наиболее значимых для русского культурного пространства произведениях и сюжетах особая роль отводится теме идее служения Отечеству - долгу. Сразу после объявления Великой отечественной войны тысячи и тысячи молодых людей выстроились на призывные посты и пункты ополчения, уходили в партизаны. В фильмах, посвященных 
гражданской войне в Америке, во множестве картин показано, как с объявлением войны плотники и лесорубы Юга, владельцы плантаций и просто мирные жители бурно встретили это известие («Унесенные ветром», «Холодная гора", или вспомним радость от начала войны с пришельцами в х/ « «Звездный десант»). Вспомним х/ «Летят журавли», где герой Баталова отказывается от «брони» и идет на фронт. Особое внимание в контексте происходящих ныне событий привлекает фрагмент из х/ф «72 метра», когда моряков Черноморского флота призывают принять украинскую присягу, на что капитан подводной лодки в исполнении Андрея Краско, прерывая речь офицера украинской армии, произносит: «Желающие принять украинскую присягу - шаг вперед. Остальные - айда за мной!» ${ }^{3}$. После чего экипаж в полном составе под музыку «Прощание славянки» удаляется. В фильме «Грань будущего» ${ }^{4}$ именно отказ героя Тома Круза выполнять свой непосредственный долг приводит его к необходимости этот долг выполнять. Слова генерала в исполнении Жженова - «чем могу» - это «обратная сторона» понимания каждым солдатом своего долга стоять до последнего. Наконец сильнейшей сценой выполнения долга, поставленной задачи является кульминационная сцена фильма «Прорыв», где пятерка, вооруженные только холодным оружием псковских десантников продолжают бой, вызвав огонь на себя. Причем долг солдата в американском кино это не всегда почетно - в фильмах «Несколько хороших парней» и «Правила боя» солдаты и офицеры выполнили долг, но после их за это судили.

Бег от какой-либо реальной угрозы в жизни на войну - также распространенный пример для обеих кинематографических школ. Вспомним сюжеты мести и поруганной чести в «Скале» 5 , где офицеры решаются на преступления, мстя за товарищей, погибших по глупости руководства. Вспомним знаменитый фильм-оперу «Волосы» М.Формана или совсем не похожий на нее х/ $ф$ «ДМБ» ${ }^{6}$, где от армии пытаются отказаться как угодно, но все равно оказываются в погонах. $\mathrm{X} / \mathrm{c}$ «Штрафбат» ${ }^{7}$ весь построен на этой концепции - ни матерый уголовник, ни жертва

\footnotetext{
${ }^{3}$ Год 2014, реж. Владимир Хотиненко Отечеству

${ }^{4}$ Год 2014, реж. Д. Лайман

${ }^{5}$ Год 1996, реж. М. Бэй

${ }^{6}$ Год 2000, реж. Ю. Качанов

${ }^{7}$ Год 2004, реж. Н. Досталь
}

доноса отказаться от перспективы стать пушечным мясом не могут, другой вопрос - как каждый из них проходит через это испытание - с мыслью либо выжить, либо грехи искупить и долг выполнить.

Страна победившая, едва ли не в самой страшной войне в истории человечества не могла не восхвалять героев, принесших нам эту победу, что нашло отражение в $\mathrm{x} / \phi$ «Освобождение» ${ }^{8}$, «Горячий снег» ${ }^{9}$, «Они сражались за Родину» ${ }^{10}$ и др. Сегодня эта ценность также поддерживается и культивируется. Достаточно вспомнить великолепную картину «Брестская крепость» ${ }^{11}$, которая несет молодым поколениям чувства гордости за подвиг их дедов и ответственности перед страной.

Вообще имеет смысл говорить о двух равнозначных периодах Вьетнам/Афганистан, Афганистан/Ирак и Чечня/Грузия, ну и, конечно, об общем облике армии. Примеров тут множество от фильма «Цельнометаллическая оболочка»" или «Олимпиус инферно» ${ }^{14}$

Американский солдат может подозреваться в предательстве (x/c «Родина»15), но всегда будет оправдан. У нас же, наоборот - подозрений может не быть, а наказание будет, например, как в х/ф «Холодное лето 53-го» ${ }^{16}$.

Вьетнам стал своеобразным переломом в американском сознании - сознании нации победителей. Сама атмосфера, окружающий мир становятся в одночасье врагом. Когда советский человек шел по Польше или Германии, позже - по Афганистану, то среда была привычной (что касается Афганистана то, речь идет, в первую очередь, о привычности ландшафта, культурное своеобразие - это отдельный разговор). Джунгли же символически представлены как темный мир, Чистилище, мир демонов, появляющихся ниоткуда. Гниющие трупы, смрад, выжигаемые напалмом деревни со стариками и детьми - все это автоматически переводит противника в категорию нелюдей, что позволяет не чувствовать себя аморально, поступая с противником так, как запрещено поступать с себе подобными. В каждом фильме о Вьетнаме жестокость бьет

\footnotetext{
${ }^{8}$ Год 1972, реж. Ю. Озеров

${ }^{9}$ Год 1972, реж. Г. Елизаров

${ }^{10}$ Год 1975, реж. С. Бондарчук

${ }^{11}$ Год 2010, реж. А. Котт

${ }^{12}$ Год 1987, реж. С. Кубрик

${ }^{13}$ Год. 2008, реж. Д. Файзиев

${ }^{14}$ Год 2009, реж. И. Волошин

${ }_{15}$ Год с 2011, реж. М. Куэста и др.

${ }^{16}$ Год 1987, реж. А. Прошкин
} 
через край - «Охотник на оленей» ${ }^{17}$, «Апокалипсис сегодня», как апофеоз - «Цельнометаллическая оболочка». Почти в каждом из этих фильмов практически документально показаны сцены насилия, причем можно вспомнить не художественную, а вполне реальную паталогическую агрессию американцев при уничтожении Дрездена ${ }^{18}$ или Хиросимы и Нагасаки. Мы вовсе не хотим сказать, что советский/российский солдат - это всегда образец чести и достоинства. В х/ф. «Война»19 герой Чадова ведет себя очень агрессивно расстреливает женщин и говорит, что все чеченцы - бандиты, есть и другие примеры.

Но тут мы и подходим к теме нашей работы - цели и ценности. Цель на войне одна - победить (вряд ли командир, настраивая солдат пред боем, предлагает им проиграть, на худой конец - не проиграть, продержаться). Пытаясь достичь цели, русский солдат ставит перед собой вполне определенные ценности: преданность отечеству, честь офицера, человечность. В конечном итоге и герой Чадова, и герой Бодрова в «Брате» ${ }^{20}$, ставя целью победу, ценностью выбирают защиту брата, друга, сослуживца. Американец ставит цель победить не в войне, как таковой, а в своей собственной. Ярчайший пример - «Спасти рядового Райана ${ }^{21}$, где, жертвуя кучей людей, совершая совершенно иррациональные с военной точки зрения шаги, американский солдат идет выполнять не менее иррациональный приказ. Точно так же происходит в другом культовом фильме «Тонкая красная линия» ${ }^{22}$, где метафора пытающейся взлететь раненой птицы олицетворяет бессмысленность происходящих военных действий с той же жестокостью, той же иррациональностью. Это удивительным образом напоминает последние слова в фильме «9 рота» ${ }^{23}:$ «мы даже не знали, что в суматохе вывода огромной армии нас просто забыли на этой дальней, никому не нужной высоте... Мы уходили из Афгана. Мы победили?» . Фильм «9 рота» - это не русский фильм, даже антирусский именно по природе своего ценностного набора. И похабщина в начале фильма, и дешевые сцены «брошенных» солдат,

\footnotetext{
${ }^{17}$ Год 1978, реж. М. Чимино

${ }^{18}$ См. напр. К. Воннегут, Бойня номер 5 или крестовый поход детей

${ }^{19}$ Год 2002, реж. А. Балабанов

${ }^{20}$ Год 1997, реж. А. Балабанов

${ }^{21}$ Год 1998, реж. С. Спилберг

${ }^{22}$ Год 1998, реж. Т. Малик

${ }^{23}$ Год 2005, реж. Ф. Бондарчук
}

и, конечно, вопрос победы. Представить себе, что герой Баталова в «Летят журавли» не победил, представить, что не победили герои «Брестской крепости», не победили герои фильмов «Аты-баты шли солдаты» ${ }^{24}$ или герои «72 метра» - невозможно, ибо ЦЕЛЬ в русском кино - именно победа, она выше, чем стремление выжить, она в Победе ДОБРА над ЗЛОМ. Но это зло всегда с человеческим лицом. Пленных немцев, душманов или чеченцев не унижают и не расстреливают на месте, как это происходит в фильмах Голливуда.

Подытоживая, можно вспомнить фильм «Хищник» ${ }^{25}$, где вся эта квинтэссенция ужаса джунглей, теней, демонов выкристаллизовывается в мифическом существе Хищника. И далее, сегодняшние западные культурные конвенции снимают различия между «теми, кто за границей огня» и теми, кто врагтеррорист. Два фильма здесь стоят особняком: «несколько хороших парней» ${ }^{26}$ и «Правила боя» ${ }^{27}$. Чтобы было понятно: в первом двое морпехов избивают третьего, используя кляп - в результате тот погибает, этих двоих судят. В «Правилах боя» командир роты морпехов эвакуирует атакуемое толпой посольство, теряя людей, отдает приказ стрелять на поражение. Героев фильмов обвиняют одних в самосуде, хотя они уверяют, что исполняли приказ, другого в самосуде без приказа. Забавная перекличка.

Фильмы заканчиваются одинаково - героев оправдывают. Примечательны эти фильмы еще и тем, что жертвы отходят как бы на второй план, они, просто имена в процессе. В «Правилах боя» идет апелляция к тому, что молодой лейтенант во Вьетнаме в бою жил меньше минуты, и решения нужно было принимать меньше, чем за минуту. В «Несколько хороших парней» произносится кодекс морпеха США: «подразделение, корпус, Бог, страна», можно вспомнить уваровские «православие, самодержавие, народность», суворовские «мы русские - с нами Бог» и «неуверенное» «in God we trust». Ценностный набор такой близкий - настолько разен.

Рассмотрим еще один пример. В фильме «Война Харта» ${ }^{28}$ американский офицер договаривается о честном суде над сослуживцем в немецком концлагере. Ситуация уже абсурд-

\footnotetext{
${ }^{24}$ Год 1976, реж. Л. Быков

${ }^{25}$ Год 1987, реж. Д. МакТирнан

${ }^{26}$ Год 1992, реж. Р. Райнер

${ }^{27}$ Год 200о, реж. У. Фридкин

${ }^{28}$ Год 2002, реж. Г. Хоблит
} 
ная. В фильме «Офицеры» 29 или в фильме «Щит и меч» ${ }^{\circ 0}$ очень тщательно показывают пытки и издевательства над пленными русскими, и ни одного Брюса Уиллиса с «честным судом» там нет.

За что играли в фильме (да и в реальности) герои фильма «Матч» ${ }^{1}$ ? Ну не за победу же во втором тайме второго матча? Матросы и офицеры в «72 метра» ${ }^{22}$ в первую очередь выполняли задание. При этом в фильме «Последний самурай» 33 судьба героя делает странную петлю. Понимая ужас геноцида индейцев, он едет в далекую Японию и, делая духовный реверс, и уже сам истребляемый, наравне с «вымирающими» самураями, понимает (только перед лицом непосредственной гибели), что «традиция», «история» и «культура»- не последние слова в лексиконе солдата.

Вывод можно сделать только один - американцев натаскивают на животность по отношению к врагу. Враг становится внутренним демоном, которого надо убить, а цель - победа - это только победа над собой. У русского «Я» всегда на втором или третьем месте - главное победа команды, страны, человечества. Вспомним хотя бы х/ $ф$ «Август. Восьмого ${ }^{34}$, где на фоне ужасов войны русские офицеры проявляют не тупую бесчеловечность, а совершают в высшей мере нравственные поступки, то же обнаруживаем мы и в военных эпизодах «12»35.

Коллективный труд и коллективная же ответственность всегда оставались в центре понимания и описания «русского менталитета», вне зависимости от политической конъюнктуры и господствующей идеологии, именно поэтому Толстой иронизирует над словами Наполеона «Voila une belle mort» (Вот прекрасная смерть $)^{36}$. Смерть, тем более во имя гордыни, смерть в одиночку, как и смерть в принципе, не может быть прекрасной. Именно поэтому в «Холодном лете 53-го» на борьбу с бандитами «встают всем миром», а предательство одного (поселянин в исполнении Ю. Кузнецова) расценивается однозначно и прощения ему нет. Вспомним и последнюю сцену, где один бывший политзаключенный без слов узнает другого и дает прикурить.

\footnotetext{
29 Год 1971, реж. В. Роговой

${ }^{30}$ Год 1968, реж. В. Басов

${ }^{31}$ Год 2011, реж. А. Малюков

${ }^{32}$ Год 2004, реж. В. Хотиненко

33 Год 2003, реж. Э. Цвик, г. 2003

${ }^{34}$ Год. 2008, реж. Д. Файзиев

${ }^{35}$ Год 2007, реж. Н. Михалков

${ }^{36}$ Л.Н.Толстой, Война и мир, т. I, гл.19, М. 1989 г.
}

Вообще вопрос личности также имеет отношение к нашему исследованию. Личность, индивидуальность - отличительная черта американского солдата. «Универсальный солдат» ${ }^{37}$, «Солдат Джейн» ${ }^{8}$, «Терминатор» 39 , серия фильмов «Перевозчик» ${ }^{40}$ и др. Сама философия американского солдата заточена на индивидуализм. В то время как индивидуализм строго порицается в русском культурном пространстве. Вспомним Теркина «Тем путем идут суровым, что и двести лет назад проходил с ружьем кремневым русский тружениксолдат» ${ }^{41}$. Опять мы обнаруживаем связь времен, чего лишено американское искусство, где современный боец в Афганистане не ассоциируется с ковбоем или солдатом времен гражданской войны.

Таким образом, мы можем нарисовать образы американского и русского солдата. Американец всегда один на «переднем плане», в то время как русский всегда будет в цепи товарищей. В прекрасном фильме «Проверка на дорогах» ${ }^{42}$ полицая принимают и кормят, a после даже берут на задание, включая его в отряд, прощая его малодушие. В x/c «Родина»43 вернувшегося из Ирака солдата до последнего подозревают в том, что он террорист.

Как видим, возвращаясь к вопросу о ценностной составляющей образов воюющих русских и американцев, можно найти некоторые сходства и различия, причем последних больше. И русский, и американец воспринимают войну как нечто противоестественное, ужасное, то, чего следует избегать. И тот, и другой осознают свою ответственность, необходимость выполнять приказ. При этом для русского противник - всегда человек. Во многих же американских фильмах враги представлены как нелюди, на которых не могут распространяться моральные законы. И русский, и американец несут в себе идею служения, но русский служит Отечеству, для американца оно оказывается не столь значимым (вспомним уже приводимый выше девиз морских пехотинцев: «подразделение, корпус, Бог, страна», где страна оказывается на последнем месте в ряду). Подводя итог и несколько

\footnotetext{
${ }^{37}$ Реж. Р. Эмерих, г. 1992

${ }^{38}$ Реж. Р. Скотт, г. 1997

${ }^{39}$ Реж. Д. Кэмерон, г. 1984

${ }^{40}$ Последний «Перевозчик 3», реж. О. Мегатон, г. 2008

${ }^{41}$ А. Твардовский, «Василий Теркин», гл. «Переправа»

${ }^{42}$ Год 1971, А. Герман

43 Год с 2011 по сей день, реж. М. Куэста и др.
} 
упрощая, скажем: американец всегда воюет за себя ${ }^{44}$, а русский - за Родину, за ближнего, за великую цель ${ }^{45}$.

Русским не свойственна агрессия, как было показано в статье, но данные о том, к чему ведет нами выбранный курс, не соответствующий базовым ценностям русского мира, говорит нам об обратном. Вернее, нас ведут к американскому ценностному выбору. Но выбор, по-прежнему, за нами.

\section{Библиография:}

1. Максапетян А. Г. Языки описания и модели мира // Вопросы философии. №2.2003.

2. Брудный А. А. Психологическая герменевтика. - М., 1998.

3. Кэмпбелл Дж. Мифы, в которых нам жить. - М., 2002.

4. Почепцов Г. Г.»Информационные войны. Основы военно-коммуникативных исследований». - М., 2001.

5. Ннг К. Г. Душа и миф. Шесть архетипов. - М., 2004.

6. Bar-Tal D. Group beliefs as an expression of social identity // Social identity: International perspectives. London, 1998.

7. Ферро М. Кино и история // ВИ. 1993. № 2.

8. Сидорова Г.П. Советская хозяйственная повседневность в образах массового искусства 1960-1980-х: гендерные особенности аксиологики труда // NB: Культуры и искусства. - 2013. - 5. - C. 70-89. DOI: 10.7256/2306-1618.2013.5.9784. URL: http://www.e-notabene.ru/ca/article 9784.html

9. В.И. Жуковский Произведение изобразительного искусства: феномен индексных, иконических и символических художественных образов // Философия и культура. - 2012. - 11. - С. 128-135.

10. М.И. Розенова Позитивная психология в России: некоторые актуальные вопросы адаптации. // Психология и Психотехника. - 2012. - 1. - С. 57-62.

11. Л.А. Грицай Гуманистическая модель семейного воспитания в педагогическом наследии Н.Н. Каринцева, И.О. Фесенко и П.П. Блонского // Педагогика и просвещение. - 2012. - 2. - С. 34-45.

12. П.С. Гуревич Здоровый человек как муляж // Филология: научные исследования. - 2012. - 4. - С. 3-4.

13. Красавин В.А. Формирование патриотического сознания школьников на документах и материалах Великой Отечественной войны // Педагогика и просвещение. - 2013. - 3. - С. 247-252. DOI: 10.7256/2306434Х.2013.3.10497.

14. Багдасарян В.Э., Сулакшин С.С. Высшие ценности Российского государства. М.: Научный эксперт, 2012.

15. А.А. Разин Типология людей по духовно-нравственным качествам // Философия и культура. $-2011 .-11$. - С. $6-16$.

16. Д.Л. Родзинский Фортуна и ее роль в античном мировоззрении философов // Философия и культура. 2010. - 1. - С. $90-100$.

\section{References (transliterated):}

1. Maksapetyan A. G. Yazyki opisaniya i modeli mira // Voprosy filosofii. №2.2003.

2. Brudnyi A. A. Psikhologicheskaya germenevtika. - M., 1998.

3. Kempbell Dzh. Mify, v kotorykh nam zhit'. - M., 2002.

4. Pocheptsov G. G.’Informatsionnye voiny. Osnovy voenno-kommunikativnykh issledovanii”. - M., 2001.

5. Yung K. G. Dusha i mif. Shest' arkhetipov. - M., 2004.

6. Bar-Tal D. Group beliefs as an expression of social identity // Social identity: International perspectives. - London, 1998 .

7. Ferro M. Kino i istoriya // VI. 1993. No 2.

8. Sidorova G.P. Sovetskaya khozyaistvennaya povsednevnost' v obrazakh massovogo iskusstva 1960-1980-kh: gendernye osobennosti aksiologiki truda // NB: Kul'tury i iskusstva. - 2013. - 5. - C. 70-89. DOI: 10.7256/23061618.2013.5.9784. URL: http://www.e-notabene.ru/ca/article 9784.html

9. V.I. Zhukovskii Proizvedenie izobrazitel'nogo iskusstva: fenomen indeksnykh, ikonicheskikh i simvolicheskikh khudozhestvennykh obrazov // Filosofiya i kul'tura. - 2012. - 11. - C. 128-135.

\footnotetext{
${ }^{44}$ См. напр. х/ф «Уцелевший», год 2013, реж. П. Берг

45 См. напр. х/с «Грозовые ворота», год 2006, реж.

А. Малюков
} 


\section{Культура и искусство 6(24) • 2014}

10. M.I. Rozenova Pozitivnaya psikhologiya v Rossii: nekotorye aktual'nye voprosy adaptatsii. // Psikhologiya i Psikhotekhnika. - 2012. - 1. - C. 57-62.

11. L.A. Gritsai Gumanisticheskaya model' semeinogo vospitaniya v pedagogicheskom nasledii N.N. Karintseva, I.O. Fesenko i P.P. Blonskogo // Pedagogika i prosveshchenie. - 2012. - 2. - C. 34-45.

12. P.S. Gurevich Zdorovyi chelovek kak mulyazh // Filologiya: nauchnye issledovaniya. - 2012. - 4. - C. 3-4.

13. Krasavin V.A. Formirovanie patrioticheskogo soznaniya shkol'nikov na dokumentakh i materialakh Velikoi Otechestvennoi voiny // Pedagogika i prosveshchenie. - 2013. - 3. - C. 247-252. DOI: 10.7256/2306434X.2013.3.10497.

14. Bagdasaryan V.E., Sulakshin S.S. Vysshie tsennosti Rossiiskogo gosudarstva. M.: Nauchnyi ekspert, 2012.

15. A.A. Razin Tipologiya lyudei po dukhovno-nravstvennym kachestvam // Filosofiya i kul'tura. - 2011. - 11 . -C. $6-16$.

16. D.L. Rodzinskii Fortuna i ee rol' v antichnom mirovozzrenii filosofov // Filosofiya i kul'tura. $-2010 .-1$. - C. $90-100$. 